1952-53, and to prevent their recurrence, to overcome the well-known obstacles to the more efficient working of such colleges and colleges of technology at the higher levels, and to keep the expansion of facilities for training technologists and technicians in balance and in harmony with the country's needs. Such questions cannot be dismissed summarily as they were by Lord Salisbury, and the Parliamentary and Scientific Committee would do well to inquire further into these and other points on which the debate threw insufficient light.

\section{LITERATURE AND SCIENCE}

\section{Literature and Science}

By B. Ifor Evans. Pp. 114. (London: George Allen and Unwin, Ltd., 1954.) $8 s .6 d$. net.

BOOK on the relationship between literature $\mathrm{A}$ and science should receive a warm welcome from both scientists and men of letters. Often the scientist has no interest in poetry, which he neither understands nor appreciates; while the artist, being largely unaware of the nature and objects of science, may feel resentful of the way in which science seems to have come to dominate men's lives. Nevertheless, the full development of the intellectual life of our times depends on the work of both artists and scientists. Both should contribute to the philosophy which guides our thoughts and actions. On both sides there should be more realization of the aims and methods by which each works; the little book by Dr. Ifor Evans gives us some insight into the mind of the poet and artist.

The influence of scientific studies on men of letters is no new problem. The author reviews the way in which poets have reacted from the Renaissance onwards. But in reading this historical survey, which occupies the greater part of the volume, considerable doubts must arise as to whether the past climates of thought on scientific matters have always been accurately depicted by the author. It may be easy for us to imagine which investigations should have impressed thoughtful Englishmen in the seventeenth and eighteenth centuries, because we know those which have stood the test of time. But it does not follow that the more lasting discoveries and theories had the greatest effect on contemporary opinion. Thus in writing of the early years of the Royal Society, the author refers to the intermingling of myth and magic and superstition with scientific proceedings. But the Fellows of the Society at that time had still to discover that some of the topics they discussed originated only in myth or mythology; for example, the idea that minerals grew in the earth from seeds was regarded as requiring serious investigation.

Again, in an interesting chapter on Wordsworth, Dr. Evans deals only with the poet's references to Newton and to mathematics. But from about the time of the poet's birth until he was fifty, British scientists seem to have been mainly interested in biology and geology. Sir Joseph Banks was president of the Royal Society for more than forty years, and the physical sciences languished. This, too, was the period when many beautifully illustrated books on flowers and birds were produced and had a wide circulation. The discussion of geological problems led to the founding of the Geological Society in 1807.
It is not improbable that Wordsworth's first visit to the Alps was inspired by de Saussure's "Voyages dans les Alpes". The second part of this beautifully illustrated work by the pioneer of alpine exploration, geology and natural history, appeared some four years before the young enthusiasts set out to walk to Switzerland.

The author shows how, in the nineteenth century, scientists and men of letters drifted apart. He considers that "the main development within the twentieth century has been the increasing uneasiness of the writer, the sense that he exists in a hostile society, and that the powers of science are increasingly creating a civilization in which he has little place". It is, however, not easy to maintain the view that the pursuit of science destroys an appreciation of the arts. Many distinguished scientists are accomplished musicians, painters or novelists. The author recognizes the merit of Sir Charles Sherrington as a poet. But those who devote all their energies to some subject, whether it be science, literature, history or golf, may well neglect other pursuits. It should be recognized that Charles Darwin, a sick man seldom able to leave his house and garden, was a special case. Perhaps one reason why poets feel neglected to-day is that so much of what they write is not readily comprehensible to the ordinary reader; it is not of the kind which one reads and re-reads in leisure moments.

In spite of the criticisms that have been made, this is an interesting book and contains much food for thought. When one reflects on the mystery and complexity of the universe as revealed by modern science, and on the disappearance of the cocksure attitude adopted by so many of the nineteenthcentury scientists, one would think that a rapprochement between scientists and poets should be possible. We scientists should take note of the author's desire for " $a$ wider act of interpretation, both of the nature of the scientific imagination and of the discoveries and possibilities of modern research".

H. Hamshaw Thomas

\section{GEOMORPHOLOGY FROM AN AMERICAN POINT OF VIEW}

Principles of Geomorphology

By William D. Thornbury. Pp. ix +618 . (New York: John Wiley and Sons, Inc.; London : Chapman and Hall, Ltd., 1954.) 64s. net.

CEOMORPHOLOGY as a science has grown up $J$ in the railway age. A hint of what was coming might be espied in those eighteenth-century travellers who, like Gilpin, began very haltingly to display an interest in the form of landscape rather than its formalized versions. A hundred years later and the trains have reached Lucerne; soon we are well into the age of physiography, that pleasant ill-defined compost which made an agreeable part of the later Victorian education. A further hundred years, and this lively branch of science has given birth to a remarkable variety of new and odd words such as pediplains, steptoes and fluviraption. Speed of communication, moreover, allows the students at a certain Scandinavian university to be flown out after the lecture to look at the land-forms from the air.

Progress has been rapid; yet the discussion of the characteristics, origin and development of land-forms 